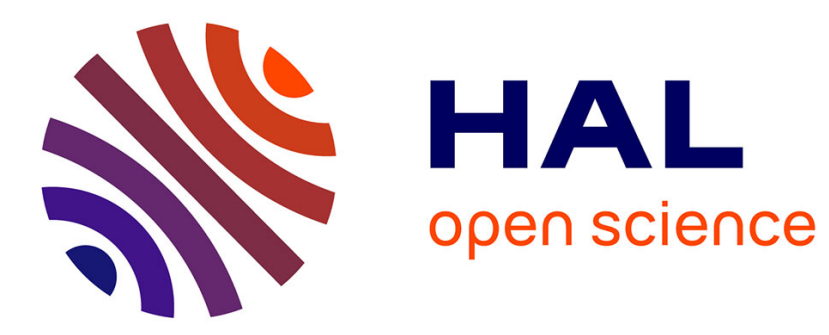

\title{
Nursing Home and Elderlies' Family: Questions about Semiospheres
}

Philippe Thomas, Gérard Chandès, Nicolas Couegnas, Cyril Hazif-Thomas

\section{To cite this version:}

Philippe Thomas, Gérard Chandès, Nicolas Couegnas, Cyril Hazif-Thomas. Nursing Home and Elderlies' Family: Questions about Semiospheres. Journal of Nursing \& Patient Care, 2016. hal-01875456

\section{HAL Id: hal-01875456 \\ https://hal-unilim.archives-ouvertes.fr/hal-01875456}

Submitted on 4 Oct 2018

HAL is a multi-disciplinary open access archive for the deposit and dissemination of scientific research documents, whether they are published or not. The documents may come from teaching and research institutions in France or abroad, or from public or private research centers.
L'archive ouverte pluridisciplinaire HAL, est destinée au dépôt et à la diffusion de documents scientifiques de niveau recherche, publiés ou non, émanant des établissements d'enseignement et de recherche français ou étrangers, des laboratoires publics ou privés. 


\section{Journal of Nursing \& Patient Care}

\section{Nursing Home and Elderlies' Family: Questions about Semiospheres}

\section{Thomas $\mathbf{P}^{1 *}$, Chandes $\mathbf{G}^{2}$, Couegnas $\mathbf{N}^{2}$ and Hazif-Thomas $\mathbf{C}^{3}$}

\begin{abstract}
Staff in a nursing home, elderly and families meets numerous difficulties during the institutionalized process in a nursing home. Some problems are linked to the development of different, sometimes competitive logics in two human groups unbalanced in terms of capacity, namely the family system and the geriatric institution. The loss of sense is the core of the moral pain for families, nursing staff and old patients. To give a meaning to the contents of what is perceived is as essential for life and biological surrounding as well. Sense is a part of person-centered care quality in a nursing home, for residents, their family, and the nursing staff quality of life at work. When an early implementation of an intersubjective approach has not been organized, negotiated and accepted by families and the nursing staff as well, possible misunderstanding or even conflicts may appear. Medical doctors, nurse-managers and psychologists can bridge the gap between the semiospheres and this have an essential role in the prevention of this drift. The question of the sense and of its elaboration in human relationships is analyzed in this article through the model of the semiosphere.
\end{abstract}

\section{Keywords}

Nursing home; Family; Elderly; Institution; Caregiver; Semiosphere; Semiotics

\section{Introduction}

Close friends and family live a very painful experience when they see old relatives losing their autonomy and being forced to enter an establishment. Families live a separation, sometimes a failure of their commitment and often a feeling of guilt not having been able to take more care of them. To leave your own home to live in a collective space, in spite of all the efforts of each to welcome elderlies, is not simple for these last ones. They are going to leave their sphere of life, their family when they are lucky enough to have one to discover an unknown nursing home. Health care providers who welcome them are structured on a hierarchical basis team, so as to working in a system of organized care, following efficient procedures and well-tried sanitary standards. Brutally, most of the time without enthusiasm for the elderlies, this system is going to substitute itself for their well-known semiosphere, the one of their close relations. Family and nursing staff belongs to two different semiospheres,

*Corresponding author: Thomas P, Psychiatrist and Geriatrician, Associated Researcher, Semiotics Research Center (CeReS. EA 3648), University of Limoges, 39 rue Camille Guerin, 87000 Limoges, France, Tel: +33 (5) 05551491 00; E-mail: philippe.thomas@etu.unilim.fr

Received: October 05, 2016 Accepted: November 15, 2016 Published: November 22, 2016 two worlds unfamiliar to each other, but they are forced to meet and to interact around the new resident of the nursing home. A good welcome in establishment is often taken into account by establishments [1]. However, in addition of these centripetal forces, centrifugal forces exist which tend to take away semiospheres. The best wills do not however prevent difficulties or conflicts [2]. In front of difficult problems of the ageing, neither families nor the nursing staffs have comfortable feelings. As a consequence, when a difficult problem arises, or when a sensitive issue is raised, both can answer in an inadequate way. Unsuitable answers of the ones generate the uneasiness of the others. The resulting loss of meaning of what is not mastered is at the heart of the moral pain. Beyond the mutual misunderstanding between old persons, families and nursing staff, the question of the elaboration of a community of sense put at the service of the elderly person is, at the same time, the difficulty and the solution of their suffering or their misunderstandings. Semiotics has heuristic resources, in particular in terms of analyses, to examine the situation and try to remedy it. We shall present in this article the general functioning of semiospheres, known by semioticians, but not so well handled in the medical environment. Our reflection tends to promote the quality of the reception of a new resident in a nursing home through the modalities of the intersubjectivity, always in mind in every situation.

\section{The semiosphere}

Semiotics studies the process of meaning, which is the production, the codification and the communication of signs. The sense, alas not always the common sense in practice, lives everywhere human activities. The meaning is not the sign. The meaning can hide under all perceptible appearances without being restricted, however, to sounds or images [3]. Find the meaning of the environment in which we live to adapt ourselves is as essential in life as the biological surrounding.

Family of elderly and nursing staff of a nursing home can be considered as the members of two different semiospheres. The semiosphere is an environment which allows sharing a meaning between its members, to facilitate the dialogue between them and with what it represents, according to Lotman [4]. The term "semiosphere" can be used in two senses, similar, but of different amplitude [5]. On the one hand, "semiosphere " can have a global sense and indicate the whole space of the meaning, for instance, my family, the care for the nursing staff. On the other hand, it represents a local space where particular processes allowing releasing meanings take place, in other words, a particular semiotic space. For instance, family is a space of relationships, whereas a nursing home, a space to promote the quality of life for elderly.

The human environments get organized themselves, structured once the sense clears a special purpose and requires to communicate. A virtual separation is created between insiders and outsiders another one separates the center, the core of the semiosphere, those who assure the meaning leadership, and the other members belonging to the periphery (binarity). The semiosphere is marked by the heterogeneity of its members, by their various opinions around shared themes, and different modalities of exchange through communications codes. The codes differ from one individual to another and sometimes are untranslatable (asymmetry), which imposes the implementation 
of process of elaboration in order to find senses. The asymmetry realizes two modalities of structuring. First and foremost, the people belonging to the center and the periphery of the semiosphere have neither the same role, nor the same privileges, and are not on the same level of authority. Secondly, the languages, the verbal, clothing, behavioral codes are different, sometimes incomprehensible from a semiosphere to another one. From these points of view, family members and nursing staff belong to two different semiospheres. For Lotman, binarity and asymmetry insure the cohesion of the semiotic system [4]. Moreover, this implies that the stability of the semiosphere should be a long-lasting one. When the semiosphere is established over time, its language and its codes evolve and may vary over time, just like a family sees children growing up and committing in new segments of the society, or like the staff of a nursing home wins benefits from some experience through its daily practice. In an interesting way, the coexistence of two semiospheres centered towards the same purpose, can lead to a harmonious co-evolution. Obviously, the objective of the care in both cases is centered on the elderly person. Nevertheless, processes in game in the family are loaded by affects, those in nursing home revolves at stake around the quality of the care. In absence of co-elaboration of a life plan for the elderly person, between family and nursing staff, a gap opens up between the two semiospheres. The admission to an institution is rarely the desire of an old person. The badly accepted, even forced passage for a dependent elderly, from the family semiosphere to the institution's one is going to upset many persons.

Every semiosphere is just like a cell (Figure 1A), with an external membrane which isolates it and puts it in connection with the outside for some modalities of exchanges, and a perinuclear membrane which isolates the center, and separates it from the periphery, allowing however organized interactions. The center of the semiosphere acts like an expert regarding the sense, it expresses the purposes, the ethics and the moral values. The center is the place of the official statement of currently prevailing rules and commonly agreed practices in a semiosphere. He has a particular authority in his speech [6]. It speaks through words and expressions chosen and adapted, in forms waited by the periphery. Generally, the center and the periphery of the semiosphere work harmoniously. The human relationships can be strained between periphery and center, especially if the semiosphere, the family or the institution, is structured in a stiff way.

\section{The expended model of semiosphere}

The Lotman's model of semiosphere is attractive and of wide implication. It allows to approach various processes of communication as well as different modalities for the training of the sense from an environment to the other one. It remains however insufficient to report the complexity of the human interactions. So, one of use proposed an expended model of the semiosphere (Figure 1B). A certain number of compartments can structure it, distributed according to the level of competence or expertise and to the functional implication of the members [7]. The modalities of communication and the relevance of the codes of language which allow to interpret the meaning of a speech or of exchanges of instructions are different according to the various levels of reading. The appropriateness of the message weakens when going away from the center to the periphery. Two models are presented, relationships in western nuclear families, on the one hand, the structuring of the staff in a nursing home on the other hand. Both models are united in an ethics and a sense of cooperation and responsibility towards others usually called "Care" [8]. This will enable us to approach the difficulties between families and nursing staff in a nursing home.
The center represents a certain degree of leadership, head of household in families or management in an establishment. The first circle, near the center, is directly concerned by a commitment in the success of the project of semiosphere, preservation of the family harmony, or quality of the care in an institution. The second peripheral circle leads to a lesser implication in the family organization or in the care. The last circle involves people not responsible for the care, as well in family as in an old people's home, but who can have a satellite role. Table 1 summarizes the common points shared in both semiospheres.

\section{Nuclear family as a semiosphere}

Transactional relationships inside the family are mainly affective. Institutionalization of an elderly person is often lived as a failure of the care given by the family, and comes along with guilt. A nuclear family is a shape of family structure based on the notion of couple, two adults living together, married or not, the center of the semiosphere, with or without children. The nuclear family is the dominant family model in western societies. Todd distinguishes the egalitarian nuclear family from the traditional nuclear family [9]. In the first one, the relationships between parents and children are of liberal and egalitarian type. The rule in the family is the dialogue and the tendency to the consensus. The institutionalization of the senior is discussed for a long time. The family's perception of the nursing staff is often friendly. Internal frontiers between the center, the parents, and the periphery, the rest of the family, is semipermeable. In a traditional nuclear family, the authority of the parents or the head of the family is not discussed. The relationships

\section{A Lotman's semiosphere}

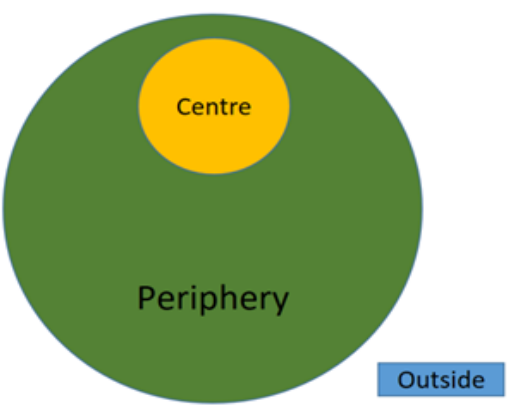

Figure 1A: Lotman's semiosphere.

\section{Expended model of semiosphere}

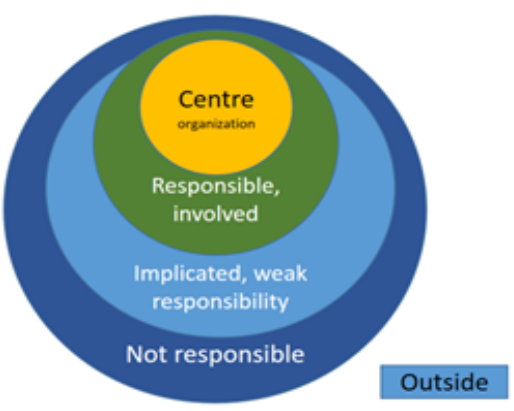

Figure 1B: Expended model 
Table 1: Common points shared in both semiospheres, family/nursing home staff. As an example, three circles of the periphery are presented.

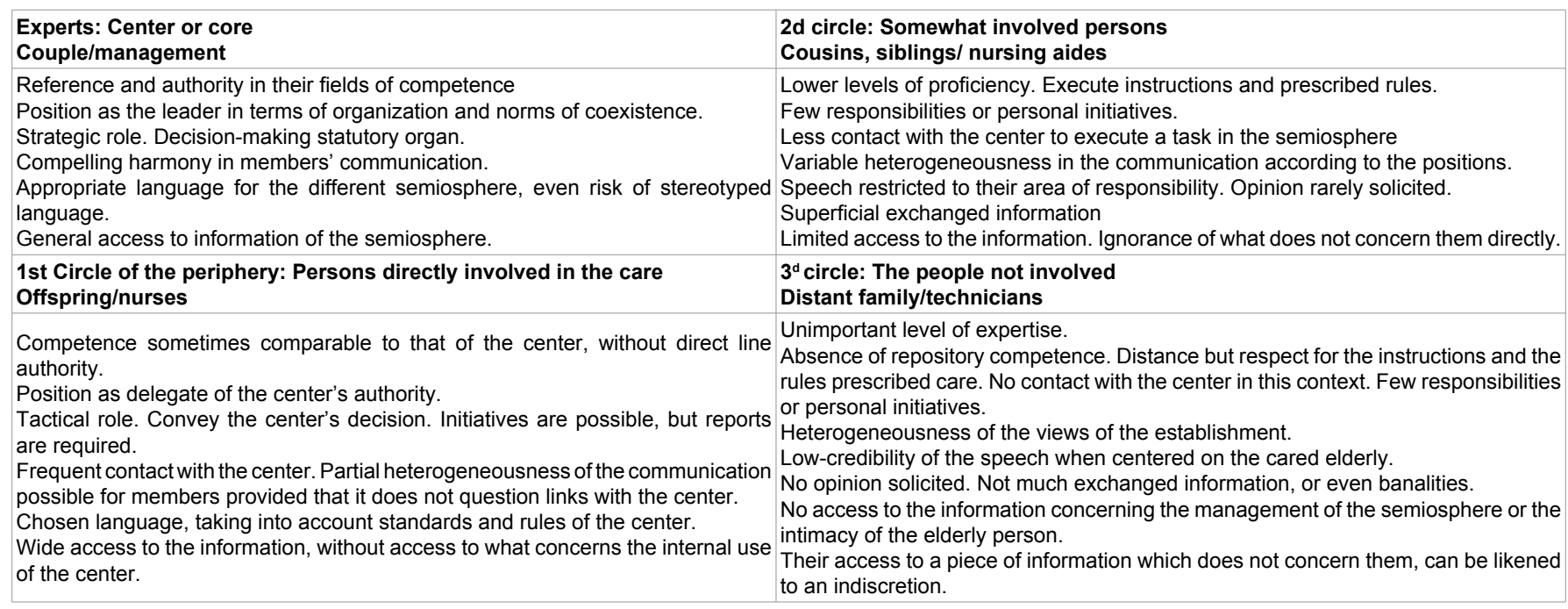

in the brotherhood are not egalitarian, the elder son, for instance, having a preponderant place. The family vision is sometimes colored with religious objectives. The rule is the respect for the hierarchy. Dialogue between parents and their children could be difficult. The institutionalization of the elderly person is sometimes authoritarian, generating senses of guilt or conflicts in the family. A consensus is not always obtained for the admission of the senior to a nursing home. Tensions are possible between the nursing staff and some members of the family. Conflicts in the family can so influence bad relationships between families and nursing staff who are responsible for nothing there. The frontier between the center and the periphery is strongly locked. The elderly person has, in this last case, an important function of communication, in particular to relay possible difficulties of their grandchildren towards the parental center [10].

The first peripheral circle of the family is usually composed of the offspring, sometimes the grandchildren. If the elderly person needs assistance, these relative are motivated to help, quickly mobilizable, at least if they do not live too far. The first circle has an important delegated role in the management of the family, in particular when the center is absent or defective (accident, disease...). The second circle is more distant from the center, and concerns the less immediate family, as uncles, cousins, nephews or some very close friends. In case of difficulties, these members of the semiosphere are not always easily mobilizable. The third circle concerns the distant family and friends. Their mobilization in case of difficulties is unpredictable. The outside of the family is outside its standards, as foreign territory.

\section{The nursing home semiosphere}

The purpose of all the old people's homes is the well-being of old residents. Families appreciate the relational qualities of the nursing staff, but too much familiarity or emotional closeness, can be lived as a breach in their intimacy. In spite of efforts of opening on the outside, a nursing home is enclosed physically and often functionally in the name of the principles of safety. The strategic decision-making body, the expert center of the semiosphere is the director, assisted at least by a nurse-manager and a medical doctor. The policy of quality of the management has a positive impact on the well-being of residents, and so limits the risk of potential conflicts with the users or their family.

The first peripheral circle is composed of the nursing staff everyday involved in a professional way in tactical missions of organization of the care, in safety of the residents and in reception families. The applicable and safety standards from the centerexpert relieve imperatives of management, the establishment, sometime subsidiary of a Group, and the sanitary regulations. Good communication is necessary to avoid the conflicts with families whose habits can be change. The second circle is constituted of staffs less committed in the technical care, what excludes by no means their dedication to the residents. They are de facto submitted to the rules of the previous circle, and they are distant from information stemming from the center. Confronted with an excessive working burden, with insufficient staff, employees of the first and the second circles are in the foreground to receive the grievances of families. Their application in the care and their commitment with the elderly expose them to burnout or psychosocial risks [11]. The third circle groups the staffs with low responsibility of organization, without direct link with the care: the maintenance operator, the secretary, the gardener... They are under the orders of the expert center but only for the instructions of their profession which puts them only rarely in the contact of the care to the residents. Easily accessible, they are often requested by families but usually cannot answer their questions. The noncompliance with the hierarchical position is a cause of conflict with families.

When establishments have an important size, they can be divided into various units, sometimes specialized, for instance for demented patients. Sub-semiospheres can appear. In the absence of a thus collaborative approach or employees' turnover between the different units, new sources of conflicts arise between the employees or with families. Medical doctors, nurse-managers, and psychologists, because they have transverse missions, have an important role regarding the quality of work life. The associations of families and the representatives of the residents in establishments must be understood by the expert center. Sense is a part of person-centered care quality in a nursing home, for residents, their family, and the nursing staff's quality of life. The best is to build together a shared meaning. Quality of care, quality of life at work, a good communication, and a listening of each one, limit the number of relational difficulties.

\section{To avoid conflicts between both semiospheres. Prevention through intersubjectivity}

The family semiosphere has its rules, its codes and its specific generational and transgenerational history. The affective relationships 
Citation: Thomas P, Chandes G, Couegnas N, Hazif-Thomas C (2016) Nursing Home and Elderlies' Family: Questions about Semiospheres. J Nurs Patient Care 1:1.

are the cement between its members and the family is watchful about its intimacy. All details are not passed on in health care teams. The nursing employees have to learn to work particularly with every family, and not with families in general. Otherwise, they may risk to have the inconvenience to hear something like: "you are not a part of our family, as far as I know. You are intrusive. Mind Your Own Business. Do your work, I pay you for it". These remarks are difficult and painful for the nursing staff. Indeed, the knowledge of the life story of a senior allows to understand better her/his personality, and thus to improve the care.

From the point of view of families, to understand the nursing staff is not so simple. An institution has its appropriate rules, internal and external regulations, sanitary standards, the staff has a workload, temporal imperatives to be respected, has to comply with the written traceability and uses specific professional codes to communicate. And all the details are not passed on to families, seniors have right to get an intimacy. A difficult family is a family which could have heard: "Here is the plan of personalized care, explanation, explanation, explanation ... You can read it and bring it back to us, for example next week." Lack of empathy is not accepted by families.

The senior needs her/his family as well as the care provided by the nursing staff. For both, the care, of course, is centered on the senior. Nevertheless, their cooperation contributed greatly to the success of the care. Regarding intersubjectivity, there is no miracle, just common sense. Mutual respect, interest for others, understanding of the difficulties and the sufferings of each are required. Members of the team and families must accept to give time to get to know one another. To find the time is not an easy way, but is proactive to limit conflicts.

\section{Conclusions}

A possible competition between family and nursing home semiospheres must be elaborated for the long term. The first relations between family and nursing staff, around the senior's admission to institution are crucial for the continuation of the stay. The conflict prevention between them requires building spaces and times for negotiation. The roles of all must be positioned in every semiosphere. Nursing staff has a narrative to be co-written with families, centered on the resident, taking into account the preservation of their interactive identities.

\section{References}

1. Thomas $P$, Hazif Thomas $C$, Thomas $S$ (2015) La qualité de l'accueil en EHPAD d'une personne âgée. La Revue de Gériatrie 40: 417- 426.

2. Thomas $P$, Hazif Thomas $C$ (2015) Prendre le risque d'investir les familles une école de vie pour les soignants. NPG Neurologie - Psychiatrie - Gériatrie 15: $290-297$

3. Greimas AJ (1970) Du sens in Pour une psychiatrie de l'ellipse: les aventures du sujet en création. Presses Univ, Limoges, France.

4. Lotman $Y$ (1984) On the semiosphere. Sign Systems Studies 33: 215-239

5. Kotov K, Kull K (2011) Semiosphere is the relational biosphere.Towards a semiotic biology, Imperial College Press, London, UK.

6. Austin JL (1955) How to Do Things with Words: The William James Lectures delivered at Harvard University, Oxford: Clarendon Press, USA.

7. Chandès G (2006) Sémiosphère transmédiévale : un modèle sémiopragmatique d'information et de communication appliqué aux représentations du moyen-âge.

8. Hazif-Thomas C, Thomas $P$ (2011) Le care au risque de la maladie d'Alzheimer : guidance accrue ou autodétermination des aidants? La Revue Francophone de Gériatrie et de Gérontologie 18: 194-199.
9. Todd E (2011) L'Origine des systèmes familiaux. Tome 1, Gallimard, Paris.

10. Mirmont J (2001) Dictionnaire des thérapies familiales. Payot, Paris.

11. Thomas P, Billon R, Chaumier JA, Barruche G, Hazif-Thomas C (2014) Psycho-Social Hazards for Staff in Geriatrics and Geriatric Psychiatry. Open J Psychiatr 4: 91-8.

\section{Author Affiliations}

Top

${ }^{1}$ Psychiatrist and Geriatrician, Semiotics Research Center (CeReS. EA 3648), University of Limoges, 39 rue Camille Guerin, 87000 Limoges, France

${ }^{2}$ Professor in Information and Communication Science, Semiotics Research Center (CeReS. EA 3648) University of Limoges, 39 rue Camille Guerin, 87000 Limoges, France

${ }^{3}$ Psychiatrist and Geriatrician, Head of Department of Psychiatry for Elderly, CHRU de Brest, Route de Ploudalmezeau, 29820 Bohars, France

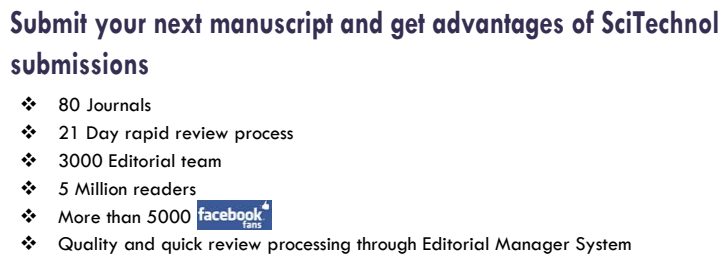

Submit your next manuscript and get advantages of SciTechnol submissions

* 80 Journals

* 21 Day rapid review process

* 3000 Editorial tean

* 5 Million readers

* More than 5000 facebook

* Quality and quick review processing through Editorial Manager System

Submit your next manuscript at • www.scitechnol.com/submission 